\title{
Lijiao: The Return of Ceremonies Honouring Confucius in Mainland China
}

Sébastien Billioud et Joël Thoraval

\section{OpenEdition}

\section{Journals}

Édition électronique

URL : http://journals.openedition.org/chinaperspectives/4927

DOI : 10.4000/chinaperspectives. 4927

ISSN : 1996-4617

Éditeur

Centre d'étude français sur la Chine contemporaine

Édition imprimée

Date de publication : 31 décembre 2009

ISSN : 2070-3449

Référence électronique

Sébastien Billioud et Joël Thoraval, «Lijiao: The Return of Ceremonies Honouring Confucius in

Mainland China », China Perspectives [En ligne], 2009/4 | 2009, mis en ligne le 01 décembre 2012, consulté le 28 octobre 2019. URL : http://journals.openedition.org/chinaperspectives/4927 ; DOI

$10.4000 /$ chinaperspectives. 4927 


\title{
Lijiao: The Return of
} Ceremonies Honouring Confucius in Mainland China

\author{
SÉBASTIEN BILLIOUD AND IOËL THORAVAL
}

Part of a larger project on the revival of Confucianism in Mainland China, this article explores the case of the Confucius ceremonies performed at the end of September each year in the city of Qufu, Shandong Province. In order to put things into perspective, it first traces the history of the cult at different periods of time. This is followed by a factual description of the events taking place during the so-called "Confucius festival," which provides insight into the complexity of the issue and the variety of situations encountered. The contrast between the authorities and minjian Confucian revivalists, as well as their necessary interactions, ultimately illustrates the complex use and abuse of Confucius in post-Maoist China.

$\mathrm{S}$ ince the start of the new century it is possible to observe in Mainland China a growing interest in the remnants of Confucian tradition. Whereas such an interest was previously confined within the academy, now it is in society that forms of Confucianism (with their sideline dreams and reinventions) have become meaningful once more. The most tangible manifestations of this popular phenomenon can be seen throughout a continuum of education, self-cultivation, and religion. However, obvious historical factors (the relationship between Confucianism and so-called "imperial ideology") as well as vague references to Confucianism and "cultural tradition" by the current regime naturally raise the question of the relationship between Confucianism and politics today.

The issue of rites and ceremonies is pivotal for Confucianism. Traditionally, they have been the nexus of what one could describe as the theologico-political dimension of power in China. In that context, what significance should be ascribed to the many ceremonies carried out today to honour tutelary figures of Chinese civilisation? This article explores the particular case of the Confucius ceremonies performed at the end of September each year in the city of Qufu, Shandong Province. In order to put things into perspective, the article first traces back the history of the cult at different periods of time. This is followed by a factual description of the events taking place during the so-called "Confucius festival," which provides insight into the complexity of the issue and the vari- ety of situations encountered. The contrast between the authorities and minjian Confucian revivalists, as well as their necessary interactions, ultimately illustrates the complex use and abuse of Confucius in post-Maoist China. In that respect, the cult of Confucius in Qufu today perpetuates an ancient tension that can be traced back to the imperial era and that is often encountered in the religious realm between the "orthodox" discourse of the authorities on the one hand, and local practices and discourses on the other hand.

\section{Historical background}

Understanding the significance of contemporary ceremonies in honour of Confucius requires first delving back into history. The following section provides a brief overview of the history of the cult and of the special circumstances of the city of Qufu across three periods: the Empire; Republican and Maoist China; and the period that commenced with China's reform and opening in the early 1980s.

\section{The cult of Confucius during the Imperial period: A few elements}

During the imperial era, the importance of the state cult of Confucius changed considerably from one period to the other, reflected in the range of titles historically ascribed to him. ${ }^{(1)}$ 
Among the titles ascribed to Confucius, an emblematic one is the title of Sage (sheng) with all its derivatives: Supreme Sage (zhisheng), Dark Sage (xuansheng), Sage of Culture (wensheng). ${ }^{(2)}$ In the same vein, one also finds the figure of the Master (shi - or first of the Masters - xianshi) with the idea that Confucius is the Master of kings, of "myriads of generations," or "of all that is under Heaven." But at some specific periods of time throughout history, Confucius was also celebrated as King or "King of the propagation of culture" (wenxuan wang), and some specialists of ritual even attempted to bestow upon him the title of Emperor. ${ }^{(3)}$ At the end of the Empire it was common to refer to Confucius as "Supreme Sage and First of the Masters" (zhisheng xianshi). To all these titles, the choice of which had some impact on the liturgy, one could also add that of Ancestor for the members of his lineage who honoured him in Qufu. ${ }^{(4)}$

It is here neither possible nor in fact necessary to enter into all the debates that historically brought people or the court to favour one title or the other or to combine them. One would merely seek to link these three figures by emphasising that the Way (the Dao) is embodied by the Sage, taught by the Master, and implemented, across the country, by the King (by the Sage King). In the end, what the state cult of Confucius celebrated was the tight connection between $\mathrm{moral} /$ cosmic and political legitimacies (zhengtong) as well as the fundamental role of education (jiaohua) in this process. If this cult did not rank - except during a brief period of time at the end of the Qing dynasty - at the top of the ritual hierarchy applied to sacrifices exclusively performed by the Emperor, this is precisely because it would have largely undermined its political function: The cult of Confucius had to be celebrated by scholar-officials, the true representatives of power, in temples and schools throughout the country. ${ }^{(5)}$

At the very heart of the ancient kingdom of Lu (in today's Shandong Province), the "holy city" (shencheng) of Qufu, where Confucius was both born and buried, occupies a special position as much in the "geography of Confucianism" as in Chinese history generally. Emperors occasionally went there to celebrate the Cult of Confucius or sent representatives to perform sacrifices in their names. ${ }^{(6)}$ At the same time, they supported the temple financially and granted a number of privileges to the Kong clan (tax exemptions, official positions, etc.). In return, the clan typically served the court loyally. It has been emphasised that for the imperial dynasties, such a "transaction" provided evidence of their legitimacy to embody the Mandate of Heaven. ${ }^{(7)}$ Even though Qufu never had the religious status of Mecca or Jerusalem
- the comparison can nowadays be heard - it nevertheless always remained a highly symbolical place for an imperial power relying on Confucianism as a state ideology.

\section{Parting with ritual: The Republican and Maoist eras}

Along with the demise of the Empire, a new period started during which Confucianism was less and less associated with rituals, even though the cult of Confucius was occasionally celebrated. In China proper, attempts to restore the cult of Confucius took place under the regime of Yuan Shikai and

The authors are grateful to David A. Palmer for his comments on a previous version of the article. This article is part of an international research project supported by the Chiang Ching-kuo Foundation and entitled "The Confucian Revival in Mainland China: Forms and Meanings of Confucian Piety Today".

1. On the different dimensions of the figure of Confucius, see Shandong sheng zhi (Gazetteer of Shandong Province), vol. 71, Kongzi guli zhi, Beijing, Zhonghua shuju, 1994, pp. 15-70, 95-96; John K. Shryock, The Origin and Development of the State Cult of Confucius, New York and London, The Century Co., 1932; Thomas A. Wilson, "Sacrifice and the Imperial Cult of Confucius," History of Religions, Vol. 41, no.3 (February 2002): "Ritualizing Confucius/Kongzi," in Thomas A. Wilson (ed.), On Sacred Grounds. Culture, Society, Politics and the Formation of the State Cult of Confucius, Cambridge, Harvard University Press, 2003, pp. 43-94.

2. The title of "dark (obscure) Sage" is linked to a story of the union of Confucius's mother with a "black God." Ibid., p. 51. On the process of "sanctification" of Confucius, see also Li Dongjun, Kongzi shenghua yu ruzhe geming (Sanctification of Confucius and Confucian revolution), Beijing, Zhongguo renmin daxue chubanshe, 2004

3. Wilson explains that Confucius was briefly revered as an Emperor in the sacrifices rendered by the Tangut Kingdom of the Xia (1032-1227). Ibid., p. 53. The title of King was suppressed under the Ming Dynasty in 1530. These titles contrast with the only official position obtained by Confucius, who was appointed Minister of Justice. During the Han dynasty, Dong Zhongshu and the Gongyang school ascribed the Spring and Autumn Chronicles to Confucius and considered him the foreteller of a reign to come, that of the "uncrowned King" (suwang).

4. See Abigail Lamberton, "The Kongs of Qufu," in Thomas A. Wilson (ed.), On Sacred Grounds, op. cit., pp. 297-332; Thomas A. Wilson, "The Ritual Formation of Confucian Orthodoxy and the Representants of the Sage," The Journal of Asian Studies, Vol. 55, no. 3 (August 1996), pp. 559-584.

5. Thomas A. Wilson, "Sacrifice and the Imperial Cult of Confucius," op. cit. p. 268. Candidates to official examinations and young people with great merit could also take part to the ceremonies: Ibid., p. 266. On rites in schools see also Christian Meyer, Ritendiskussionen am Hof der nördlichen Song-Dynastie (1034-1093), Sankt Augustin, Monumenta Serica Monograph Series LVIII, 2008, pp. 349-354. Analysing the State cult of Confucius at the end of the Qing dynasty (and its promotion to the status of "grand sacrifice"), Yapei Kuo shows how "Confucius was remodelled from one of many great sages and sage-emperors of timeless truth in the imperium into a new image of the nation." Yapei Kuo, "Redeploying Confucius," in Mayfair Mei-Hui Yang (ed.), Chinese Religiosities, Afflictions of Modernity and State Formation, Berkeley, University of California Press, 2008, p. 67.

6. The local gazetteer of Shandong Province explains that throughout history 12 Emperors went to Qufu in order to celebrate the Cult of Confucius (for a total of 20 celebrations with the Emperor attending himself). Shandong shen zhi, op. cit., pp. 96-98. Starting from the Tang dynasty, temples dedicated to Confucius (kong miao or wen miao) were erected all across the country. See John K. Shryock, The Origin and Developement of the State Cult of Confucius, op. cit., pp. 134-135; Thomas A. Wilson, "Ritualizing Confucius / Kongzi," op. cit., p. 72. Wilson explains that these temples could be found at the capital, at the provincial capitals or in all the county seats. Local elites gathered twice a year in order to offer sacrifices to Confucius. Thomas A. Wilson, On Sacred Grounds (introduction), op. cit., pp. 2-3.

7. Abigail Lamberton, "The Kongs of Qufu," op. cit., p. 328. 
its successors, at the initiative of warlords or during the New Life Movement launched in 1934 by the Kuomintang. ${ }^{(8)}$ Ceremonies to honour or invoke Confucius (e.g., spirit writing sessions) were also carried out in Republican China and later on in Taiwan by what Prasenjit Duara coined "redemptive societies," among the most famous of which were the Yiguandao (The Way of Pervading Unity, a recognised religion in Taiwan since 1987) and the Universal Morality Society (Wanguo daode hui). ${ }^{(9)}$ In Japan, an original synthesis between Confucianism and Shintoism translated during the 1930s into ceremonies honouring Confucius carried out by Shinto priests. ${ }^{(10)}$ In Taiwan in 1966, at the very time that the Cultural Revolution started on the Mainland, the Kuomintang launched a Movement for a Chinese Cultural Renaissance (Zhonghua wenhua fuxing yundong) that generated reform of the temples and ceremonies honouring "the Great Accomplisher, Supreme Sage, First master Confucius" (dacheng zhisheng xianshi Kongzi). ${ }^{(11)}$

In summation, after the dismantlement of the Empire, the strength of the political and symbolical reference to Confucius previously crystallised in the cult did not totally disappear, but depending on historical circumstances it was embodied by different regimes or organisations and in different territories. The end of the Chinese Cultural Renaissance Movement in Taiwan more or less corresponded with a time in which space slowly reopened for the symbolical appropriation of Confucianism on the mainland. Before we turn to that point, it is necessary to briefly introduce the situation of Qufu during a large part of the twentieth century.

A local gazetteer makes it possible to trace back pivotal elements in the history of the cults to Confucius in Qufu during the Republican era and to get a better understanding of the Maoist period. After the end of the empire, the cult was no longer continuous and reflected the vicissitudes of Chinese history. Apart from cults performed by specific movements and societies (e.g., the Society for Confucian Religion or kongjiaohui), official cults emerged several times at the beginning of the Republican era under the instructions of the Beijing authorities. ${ }^{(12)}$

In 1934 (the year during which the New Life Movement was launched), a great ceremony to celebrate Confucius's birthday was organised in Qufu by the Nationalist government in Nanjing with extensive press coverage. In 1938, the Japanese took Qufu. The Nationalist government that fled to Chongqing was later on replaced in Nanjing by the collaborationist regime of Wang Jingwei. The local gazetteer mentions cults ceremonies carried out in 1942 and 1943 in the presence of high dignitaries of this regime. In 1945, at
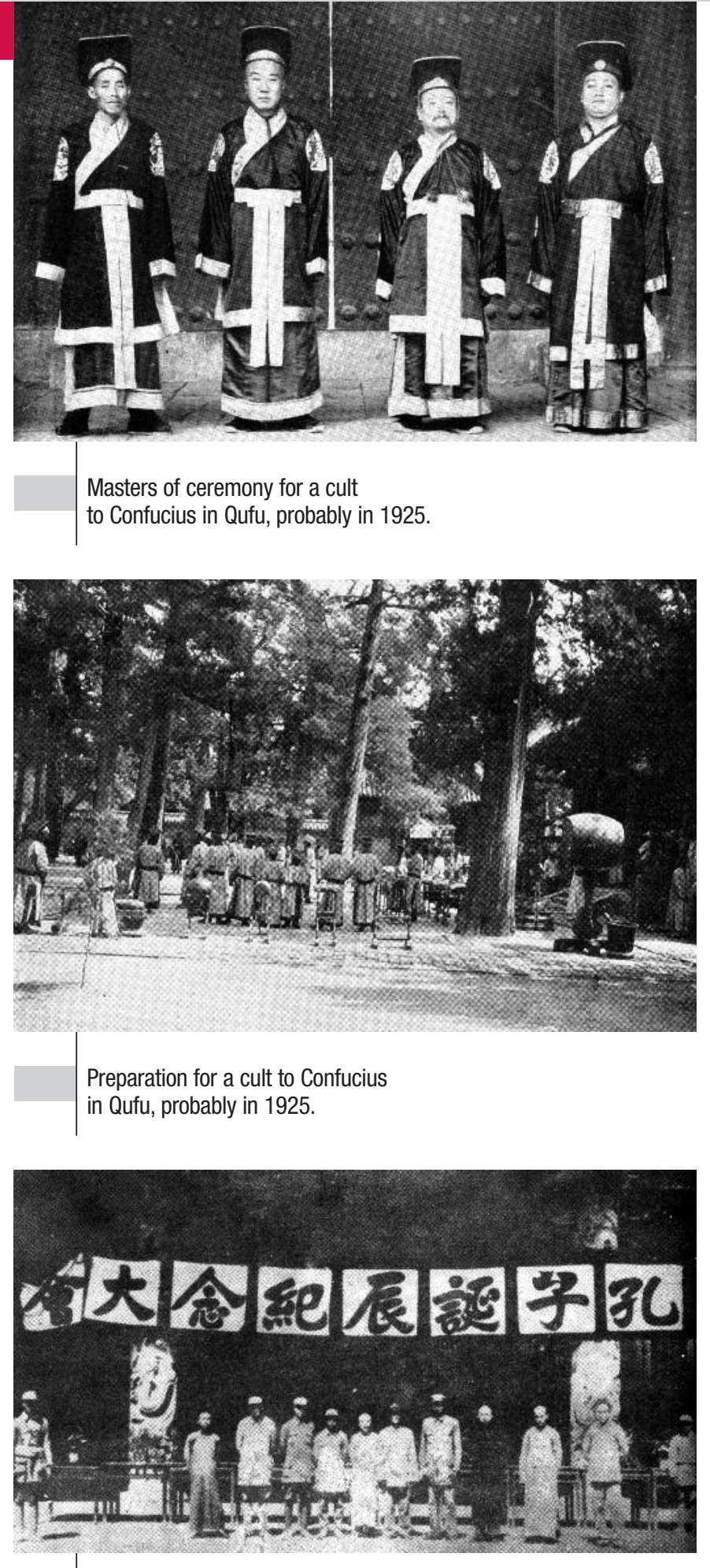

Some PLA representatives attended the 1946 commemoration of Confucius' birth.

8. Gan Chunsong, Zhiduhua rujia ji qi jieti (Institutionalised Confucianism and its dismantlement), Beijing, Zhongguo renmin daxue chubanshe, 2003, pp. 327-335.

9. Prasenjit Duara, Sovereignty and Authenticity, Lanham, Rowman \& Littlefield, 2004.

10. Nakajima Takahiro, "Xiandai Yazhou de gudian huigui” (The classical turn of contemporary Asia), section 5, Proceedings of the conference Zhongguo chuantong wenhua zai dangdai zhongguo de juese, Tokyo University, 6-7 March 2008; Warren W. Smith, Confucianism in Modern Japan, A Study of Conservatism in Japanese Intellectual History, Tokyo, Hokuseido Press, 1973.

11. Minakuchi Takuju, "Reforms of the Confucius Temple and Chinese Culture Renaissance Movement: The Situation in Taipei in 1968-70," Proceedings of the conference Zhongguo chuantong wenhua zai dangdai zhongguo de juese, Tokyo University, 6-7 March 2008. 
On the left: The Yanshen Duke, Kong Decheng, participated to the 1947 ceremonies in Qufu.

On the right: Destruction of the ancient Confucius statue during the Cultural Revolution. The characters on the trunk indicate: "No.1 big bastard!"

the time of the united front against the Japanese, the gazetteer mentions that some Communist troops entered Qufu and that a large meeting took place commemorating the birthday of Confucius. 1947 is the last year for which it is possible to trace indications of a cult of Confucius in the gazetteer. Chiang Kai-shek, back in

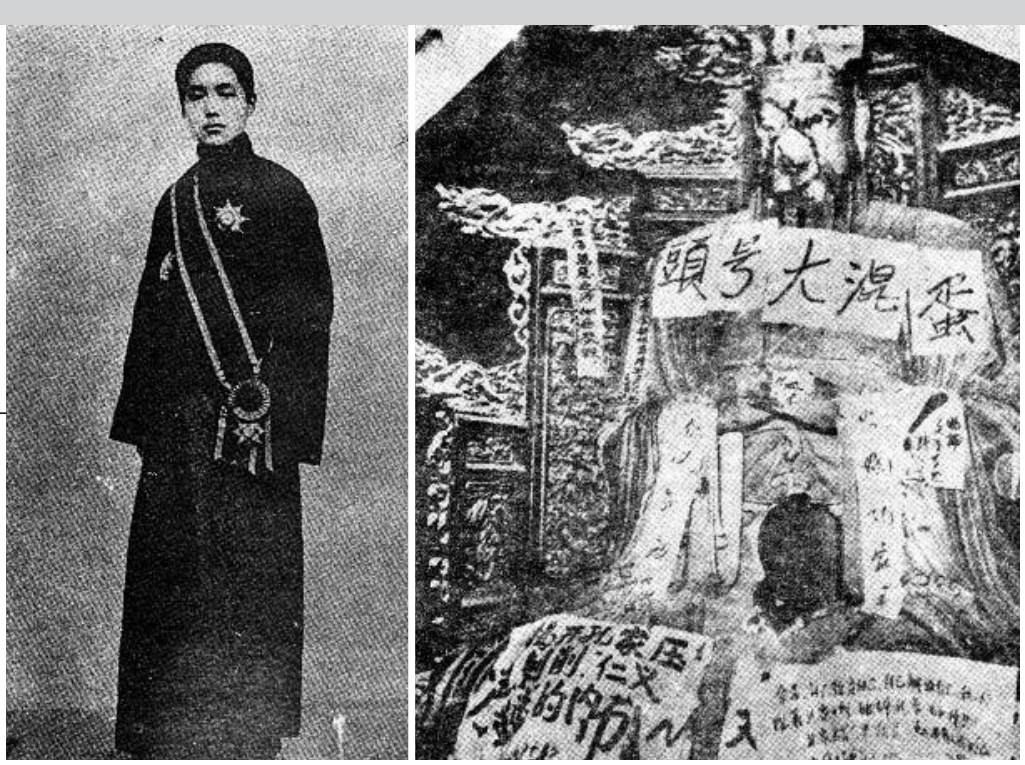
Nanjing, sent a representative to assist the descendant of Confucius, Kong Decheng, during the ceremonies. In June 1948, the PLA entered Qufu, opening a new era. ${ }^{(13)}$

In short, from the end of the Empire to the arrival of the Communists, a number of ceremonies to honour Confucius continued to be organised at a time when Qufu was controlled by extremely different regimes. The ceremonies were not necessarily regular or equivalent in scope. Moreover, they were probably the results, in these changing political circumstances, of a variety of different and specific objectives. However, by trying to identify some common points we may be able to posit that these ceremonies were all organised to provide the prevailing regime with some sort of symbolical and moral authority, or in Duara's terms, some kind of "intemporal identity and authenticity." (14)

The arrival of the Communists in Qufu probably marked the end of official Confucian cults in the city. ${ }^{(15)}$ State leaders went to the city, occasionally visited "cultural sites," and sometimes demonstrated concern for heritage preservation, but not for rites and cults. ${ }^{(16)}$ During the Cultural Revolution, Qufu went through a critical period. By chance, the Confucius temple was not destroyed, but the Red Guards, in spite of local resistance, organised their own large "ceremony," during which a statue of the Sage and a number of relics were burnt. ${ }^{(17)}$

During the Maoist era, the city definitely lost the symbolic dimension it had been endowed with for centuries. The situation would slowly change during the period of reform and opening to which we now turn.

\section{Reform and opening and the return of Confucius}

The end of Maoism and the start of the reform policy paved the way for the gradual return, over three decades, of elements of traditional culture. Confucianism benefited from this overall situation resulting from calculated tolerance by the authorities. Before the beginning of the twenty-first century, its return to the fore was still largely an academic phenomenon. ${ }^{(18)}$ Since then, the situation has changed significantly, and reference to Confucianism now appears in larger

segments of the population in a variety of different forms. ${ }^{(19)}$ The afore-mentioned "de-ritualisation" of Confucianism has already contributed to a transformation of the figure of the Master (shi) into a "thinker" (sixiangjï) or "educator" (jaoyujia), dimensions that the authorities continue to favour today. At the same time, some segments of society now refer to Confucius as a Sage or a Saint whose teachings constitute the basis for self-cultivation. Some even allude to the "uncrowned king" (suwang) of the Han dynasty... Confucius also sometimes acquires the status of a cultural hero or emblem of "cultural China" (wenhua zhongguo) that goes beyond the frontiers of nation-states. Finally, he has also become a tourist icon and focus of economic interests... It is this overall context that needs to be kept in mind in order to explore the current situation in Qufu.

12. In 1914, Yuan Shikai asked that the cults resume throughout the country. It is not specified in the gazetteer whether he personally attended the Qufu ceremonies that year. In any case, the gazetteer explains that a ceremony headed by the Da Zongtong and in which 100 civil servants participated took place in Qufu. Shandong shen zhi, op. cit., p. 48. Rites are also mentioned for the years 1921 and 1925. It is probably the preparation of the 1925 ceremonies that are described by Franz Xaver Ballas in his Konfuzius und sein Kult, Beijing and Leipzig, Pekinger Verlag, 1928. The book provides a direct testimony about the liturgy as well as a few very interesting iconographic documents. Chiang Kai-shek went to Qufu in 1928, but only to visit the place and meet the Yansheng Duke Kong Decheng, descendant of Confucius.

13. See Shandong shen zhi, op. cit., pp. 48-56; Kong Fanying, Yansheng Gong fu jian wen (Things seen and heard at the mansion of Duke Yansheng), Jinan, Qi Lu shushe, 1992, pp. 139-201. The author mentions cults in the years 1919, 1940, and 1947, providing details about the ceremony and liturgy each time.

14. Prasenjit Duara, Sovereignty and Authenticity, op. cit., pp. 30-33.

15. There is no longer any mention of the cult in the gazetteer. One cannot rule out completely the existence of a local cult that would have continued during the first years of the PRC (as for instance in the case of the cult of Huangdi), but it is very unlikely that the authorities organised anything significant.

16. In 1957, a performance took place in the Confucius temple along with the projection of a documentary film. A program of research on dances and music linked to the Confucius temple in ancient China is also mentioned. Somehow, the temple was turned into a museum.

17. Wang Liang, "The Confucius Temple, Tragedy of the Cultural Revolution" in Thomas A Wilson (ed.), On Sacred Grounds, op. cit., p. 394. The local gazetteer does net tell us much about the years of the Cultural Revolution, and there is a total blank for the years 1967, 1968, 1969, 1971, 1972, 1975, and 1976

18. See John Makeham, Lost Soul: 'Confucianism' in Contemporary Chinese Academic Discourse, Cambridge, Harvard, 2008

19. See Sébastien Billioud and Joël Thoraval, "Anshen liming or the Religious dimension of Confucianism," in China Perspectives, no. 2008/3, pp. 88-106; "Jiaohua: The Confucian Revival Today as an Educative Project,” China Perspectives, no. 2007/4, pp. 4-20. 
The prospect of massive investment (30 billion yuan) in the establishment of a "symbolic city of Chinese culture" hit the headlines, as can be seen here on the cover page of China Newsweek, 10/2008.

The local gazetteer to which we refer above provides some valuable indications about the origins of the ceremonies organised today. At the end of the 1970s, the authorities in Qufu began to relate to Confucius in a positive way through academic activities and exhibitions. At the same time, some heritage preservation work was carried out in the so-called "three Kongs" (the temple of Confucius or Kongmiao, his Mansion or Kongfu, and the cemetery, Konglin). The year 1984 was a landmark, first with the establishment in Qufu of the "Confucius Foundation" (Kongzi jijinhui) headed by $\mathrm{Gu} \mathrm{Mu}$, a member of the State Council, and secondly with the inauguration of a yearly tourist program coined "Travel to Confucius's homeland on the occasion of his birthday." ${ }^{(20)}$ The program included not only visits to the site but also a performance of ancient ritual dances. In 1989, this program was abandoned and replaced with a "Confucius Festival" (Kongzi wenhua jie) that today constitutes the framework of activities that we will expound on in subsequent sections of this paper. One year later, the festival acquired an "international" dimension (guoji Kongzi wenhua jie) and gained the support of UNESCO. At the same time, the Confucius Foundation multiplied the activities in Qufu, sometimes in partnership with entities such as the Singapore-based Institute of East Asian Philosophies that played a crucial role in the Confucian "revival" of the 1980s and, by extension, of the following decade. ${ }^{(21)}$ Among other visitors to Qufu, the Foundation invited Lee Kwan Yew, by then famous for his promotion of socalled "Asian values." Whereas at the beginning of the 1980s the interest for Confucius was largely linked and limited to tourism (and its financial bonanza) and academic projects, the remainder of the 1980s and the 1990s brought the gradual return of a political and symbolical dimension.

It is possible to gain insight into what is currently at stake by exploring the astonishing current project of creating a "symbolic City of Chinese culture" in the Qufu area (official name: Zhonghua wenhua biaozhi cheng), which some people have dubbed the "holy city of oriental culture" (dongfang wenhua shencheng), "common spiritual sanctuary of the Chinese nation" (Zhonghua minzu gong you jïnsheng jiayuan), or even "cultural vice-capital" (wenhua fudu). ${ }^{(22)}$ This massive project (the figure of a 30 billion yuan investment was circulating before the financial crisis), initiated by provincial authorities and endorsed at the central level, consists of creating a national symbolical space in an area that encompasses Qufu, Zoucheng (the native city of Mencius), and the Mountain of the Nine Dragons (Jiulongshan) located between these two spots. ${ }^{(23)}$

Obviously, the project has a strong Confucian flavour or,

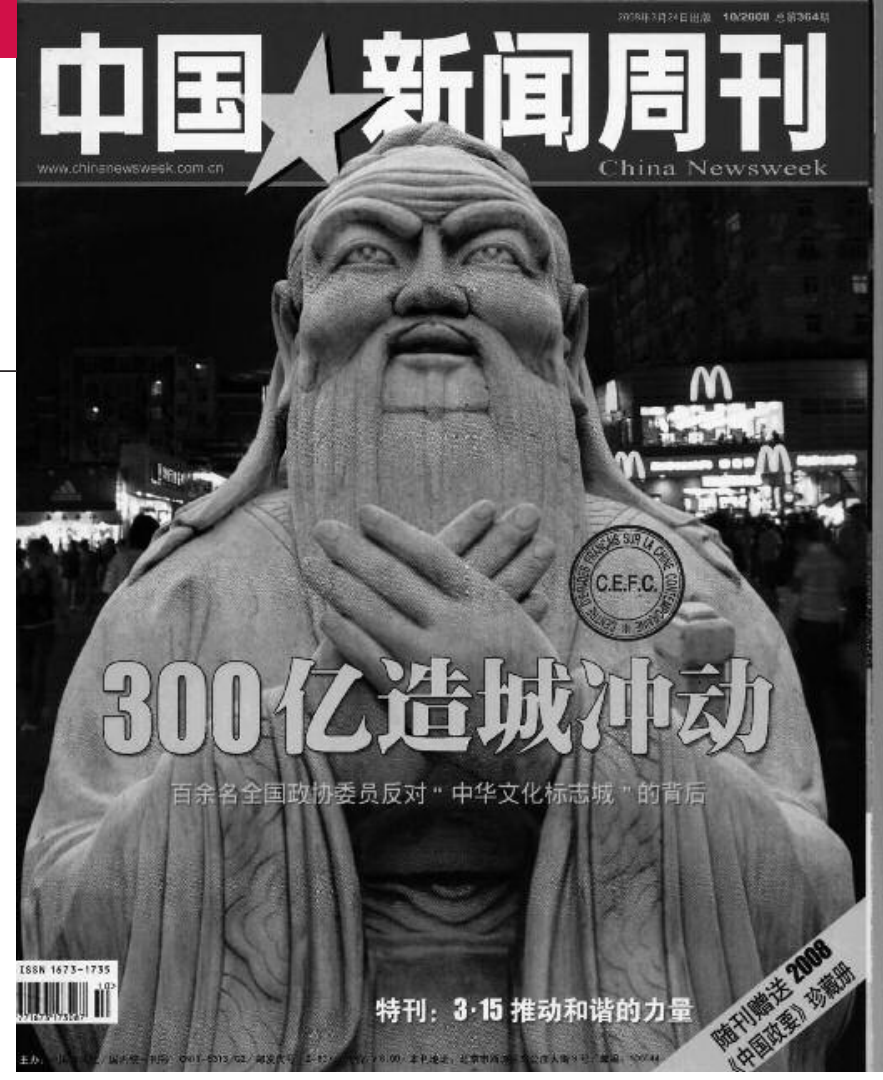

more broadly, a pronounced flavour of traditional culture, even though it is not conceived as restricted to those dimensions. More generally, it is supposed to serve three main functions: First, it would be used as a space of presentation (zhanshi gongneng) of Chinese culture and civilisation through renovated sites and museums. Second, the area at the heart of the project would constitute a space of commemoration (jinian gongneng) of ancestors, ancient sages, philosophers, heroes, and martyrs, thanks - among other plans - to the construction of some sort of Pantheon. Third, the project should also contribute to moral uplift and edification of the people (dehua gongneng). ${ }^{(24)}$ The days have truly passed when Chairman Mao praised Qufu mainly for the outstanding production results of its agricultural cooperative... ${ }^{(25)}$ The controversy stirred up by the project has been

20. Shandong shen zhi, op. cit., pp. 657-658. The purposes of the program seem exclusively tourist-related.

21. See Tu Wei-ming, Confucian Ethics Today: The Singapore Challenge, Singapore: Federal Publications, 1984; for an overview see John Makeham, Lost Soul, op. cit., pp. 21-41.

22. These different names can be found on the official web site of the project (www.ccsc.gov.cn) or in the declarations of people that took part in its blueprint.

23. The project was the object of very prominent media coverage during the 2008 session of the CPPCC and generated fierce controversy. The project was originally a local initiative (probably linked to local economic development perspectives). However, it subsequently received the support of the country's top leaders (the website explicitly mentions the support of Hu Jintao and Wen Jiabao), and its implementation has been authorised by the National Commission for Development and Reforms (NDRC). For more details on the project, see the above-mentioned website as well as Zhongguo xinwen zhoukan (China Newsweek), 10/2008, 24 March 2008, pp. 27-39 (special feature of this issue); Liaowang dongfang zhoukan (Oriental Outlook), 10 April 2008, pp. 89-81; Nanfang Zhoumou, 10 April 2008, section D, pp. 21-22.

24. http://www.ccsc.gov.cn/qwfb/200802/t20080227_3221728.html, visited on 25 May 2008.

25. Mao Zedong evoked Qufu in a speech delivered in 1955, but mainly to invite the visitor, beyond his tour of the temple and cemetery, to also visit the agricultural cooperative whose results were deemed outstanding: "Socialism is infinitely worthier than Confucian classics," Xu Quanxing, Mao Zedong yu Kongfuzi, Beijing, Renmin chubanshe, 2003, p. 324. 


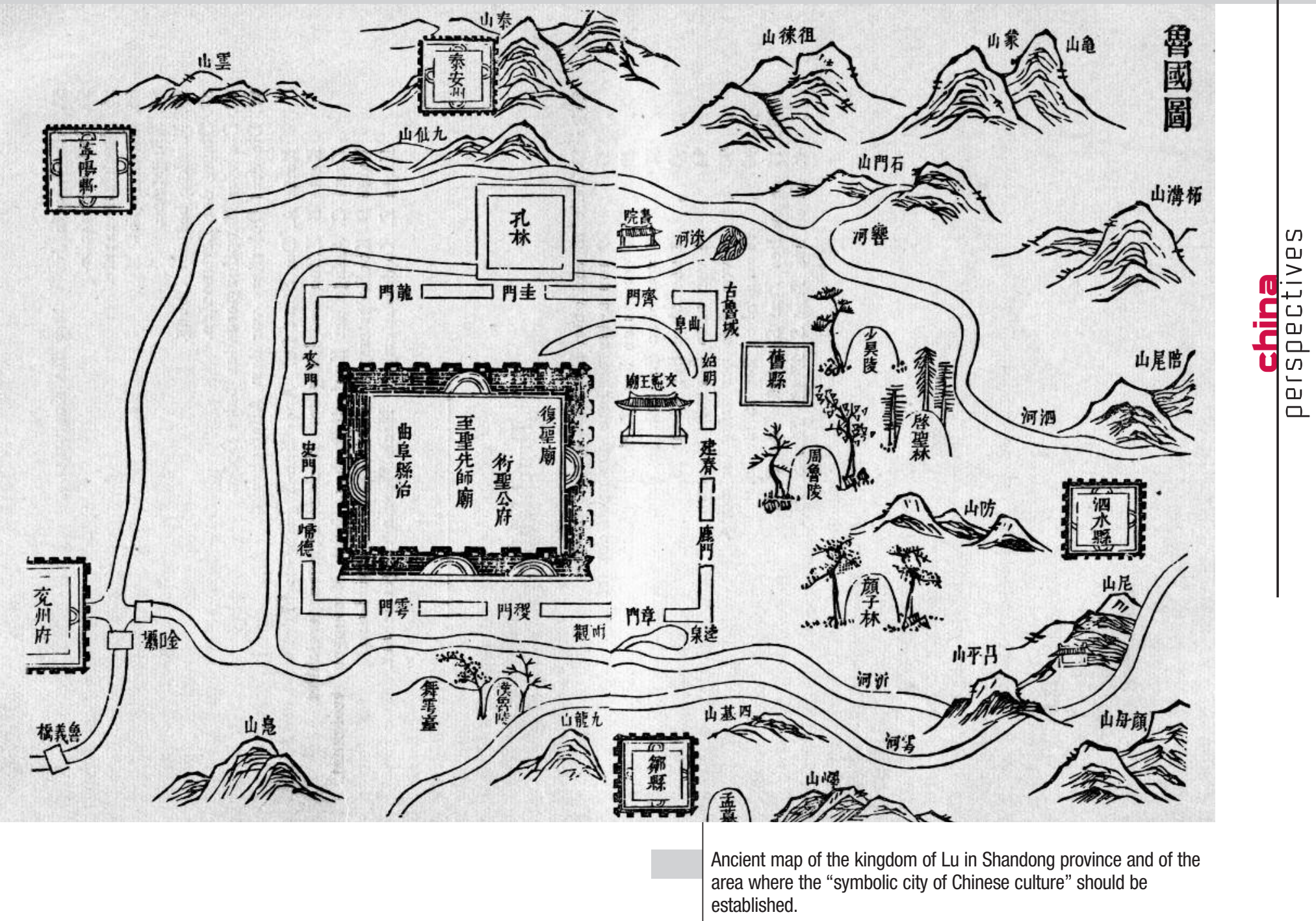

fierce, and it is difficult to foresee at this point to what extent it will be implemented. ${ }^{(26)}$ In any case, the "Holy City" (compared to Mecca or Jerusalem on the website of the project ${ }^{(27)}$ ) at least crystallises all the ambiguities of the current rediscovery of traditional culture and Confucianism: local imperatives of economic development that may be fuelled by tourism; display of some sort of "authenticity" and identity by upper-level authorities (including central government officials); and a "creative" appropriation by the population of fragments of its past and its "tradition."

\section{Confucius ceremonies in Qufu: From ritual to festival and back.}

Qufu, 26 September - 4 October 2007. Organised at the occasion of the yearly celebration of the $2,558^{\text {th }}$ Birthday of the Sage, a series of events provide some fascinating clues about what could be coined the "Confucius phenomenon." It is possible to distinguish between two different strata of phenomena: On the one hand, the involvement of the authorities at different levels; on the other hand, a number of initiatives from Confucian activists at the grassroots level that also appeal for some sort of "negotiation" with the authorities.

\section{Various activities organised in Qufu at the initiative of the authorities}

Qufu, 27 September 2007. A bus heads quickly across the city, escorted by a couple of police cars, lights flashing. On this rainy Autumn morning, traffic is blocked in the centre of

26. During the annual session of the CPPCC in March 2008 in Beijing, the representatives of this institution's Shandong provincial committee asked for funding from the central government. Such an initiative generated fierce reactions, and two petitions by members of the CPPCC opposed this project of constructing a symbolic city. The polemic and arguments of both sides have been largely discussed in the press and on the Internet. Among the main arguments opposing the project we have: (a) the huge cost of a project that is not considered a priority (let us emphasise, however, that the figure of 30 billion yuan has never been confirmed) and the question of the legitimacy of central funding for that kind of project; (b) the fact that a project with such symbolic ambition has never been discussed by the NPC and CPPCC; (c) the fact that the recommendations of experts from the Academy of Sciences and other scholars (several reports have been written) have replaced any real scientific debate; (d) the fact that the project neither represents the whole of traditional culture nor reflects the diversity of nationalities that make up the country; (e) the fact that the symbolic dimension of a city is the product of time and not an artificial construction. On these points see the afore-mentioned documents.

27. http://www.ccsc.gov.cn/qwfb/200802/t20080223_3216137.html, visited on 26 May 2008 
Qufu Stadium, 27 September, in the evening. In a most chaotic fashion, a dense crowd flocks to the gates to attend the inauguration ceremony of the International Confucius Festival. High-ranking officials are abundant. ${ }^{\left({ }^{(4)}\right)}$ Both the benches and the central space are packed with an audience of thousands (possibly tens of thousands) of all ages and backgrounds. In one of the stands, people can be seen carrying pictures of Yu Dan, the media icon for many of those rediscovering classical texts today. Impressive towers provide a backdrop, and large screens have been installed to enable people to follow the show, while television teams take their place on scaffolding. Sponsors of the event include a local Confucius wine company, whose banner advertisements are displayed above the stands. Projectors illuminate the scene, and in the background three large Chinese characters twinkle in the night: Zhonghua qing (中華情).

Zhonghua qing: that is the theme of this inaugural evening of the festival. The expression is less common than guoqing, which refers to the intrinsic circumstances of the country. It is an expression of Chineseness, the fundamental character of China understood as an entity that goes beyond frontiers (overseas Chinese are also included, and maybe even all those linked to China by blood or culture) and ethnic origin (i.e., minorities are also included). Lasting slightly more than two hours, the show features a mix of choreography inspired by the past, contemporary pop music, and allusions to and praise of Confucius. The program is organised around three themes epitomising this "Confucian Chineseness": the idea of a community, respect for differences, and the dream of a grand world unity that finds its symbolic crystallisation in the Olympic Games in Beijing. ${ }^{(35)}$ Throughout the program, a triple dimension of Chinese culture is put to the fore: local (the community of Chinese people, even when they are "scattered across the four seas"), regional (the sinicised world, harmonious beyond its differences, under the benevolent influence of Confucius), and universal through the ancient Datong (Great Unity) utopia. The program benefits from a sophisticated scenography. During the performances, symbols of Chinese civilisation (dragons, the Hundred Families surnames, the Great Wall, characters on rice paper, etc.) are projected on gigantic screens while huge balloons with the names of Confucius, Mencius, and the Confucian disciples Zengzi and Yan Hui rise slowly over the stadium. It is under these tutelary figures that Mina, a suggestively garbed young female Korean singer, offers a frenzied rock song to the enthusiastic crowd. The fervour of the audience, already increasing during the previous performances, reaches a climax at that moment, contrasting with the relative apathy during the sermons on China and its 5,000-year-old culture.

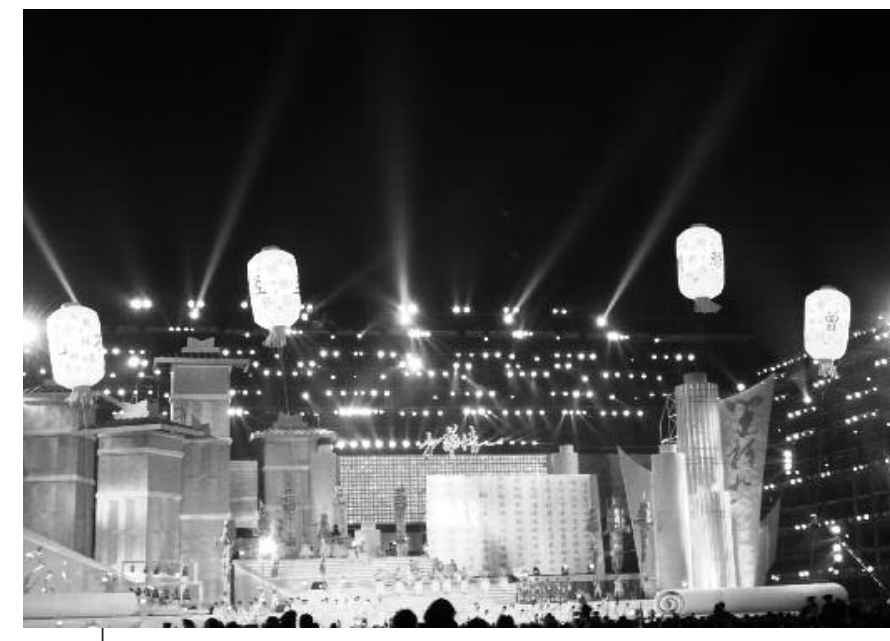

Confucius festival in Qufu stadium. Names of Confucius and two of his disciples as well as the name of Mencius can be read on the balloons rising slowly over the stadium. One can also distinguish the three twinkling characters: Zhonghua qing. @ Sébastien Billioud

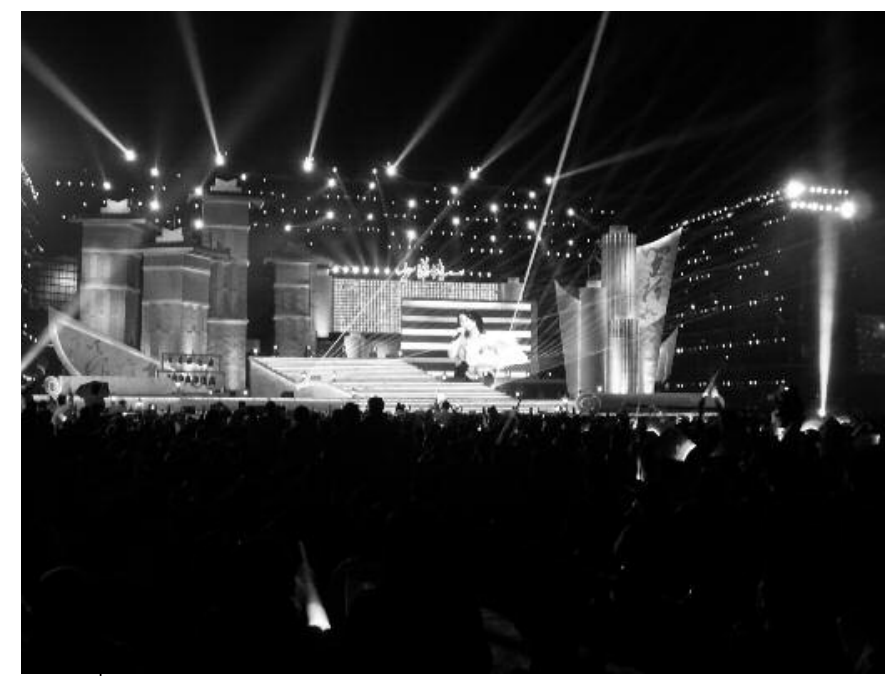

Big show in Qufu stadium, 27 September 2007 (c) Sébastien Billioud

34. Noteworthy attendees of the inauguration ceremony include the Vice-President of the CPPCC, Luo Haocai; two members of the standing committee of the NPC, Lin Zhaosu and Zeng Xianzi; the Vice-Minister of Culture, Zhou Heping, and of Education, Li Weihong; the Vice-Director of the National Bureau of Tourism, Wang Zhifa; and the President of Tsinghua University, Gu Binglin. See Qi Lu wanbao, 28 September 2007, p. A3. 


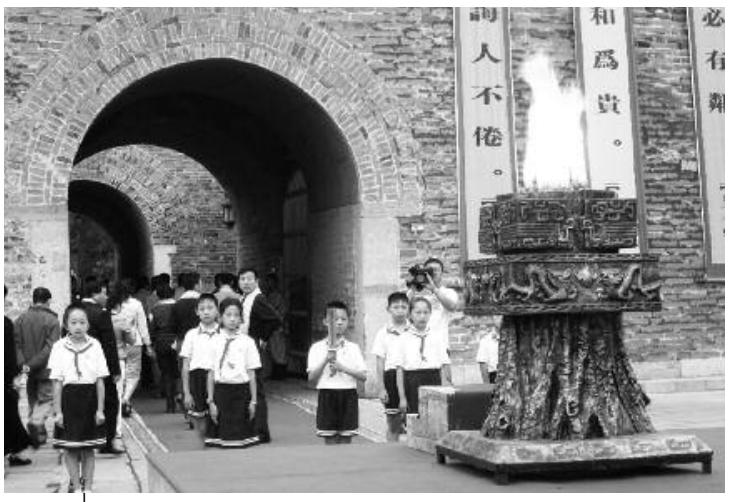

The ceremony known as "lighting the holy fire of Chinese culture. @ Sébastien Billioud

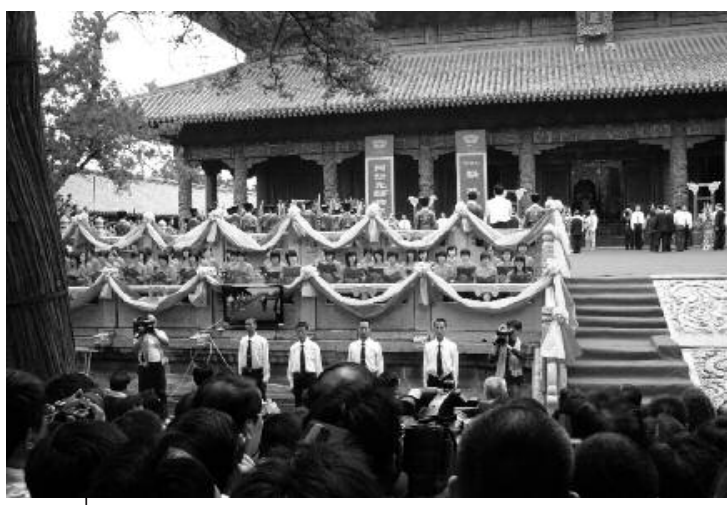

Ceremony in the Kongmiao: In the first row, PLA soldiers in "civilian uniforms"; behind them, readers of the Lunyu; in the back, dancers and officials offering baskets of flowers. @ Sébastien Billioud

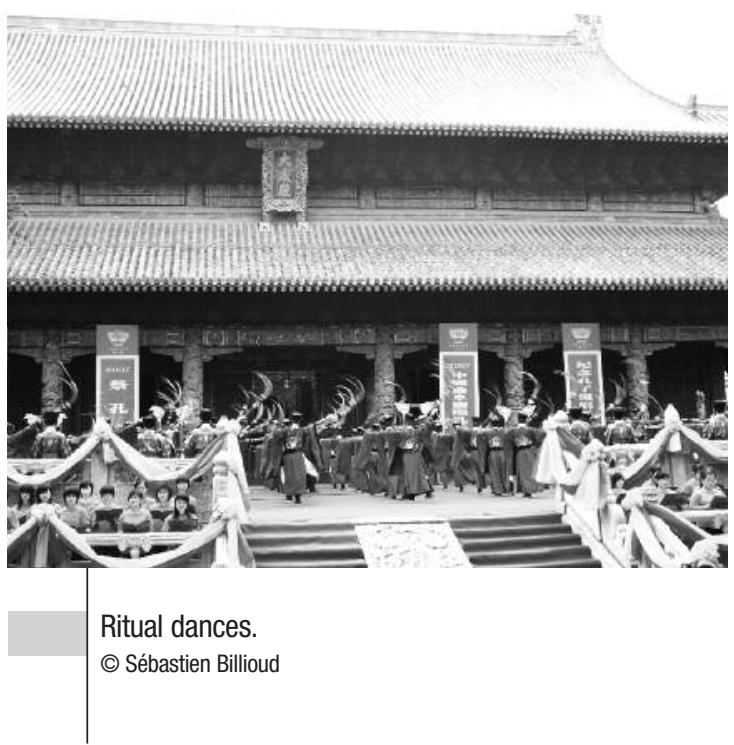

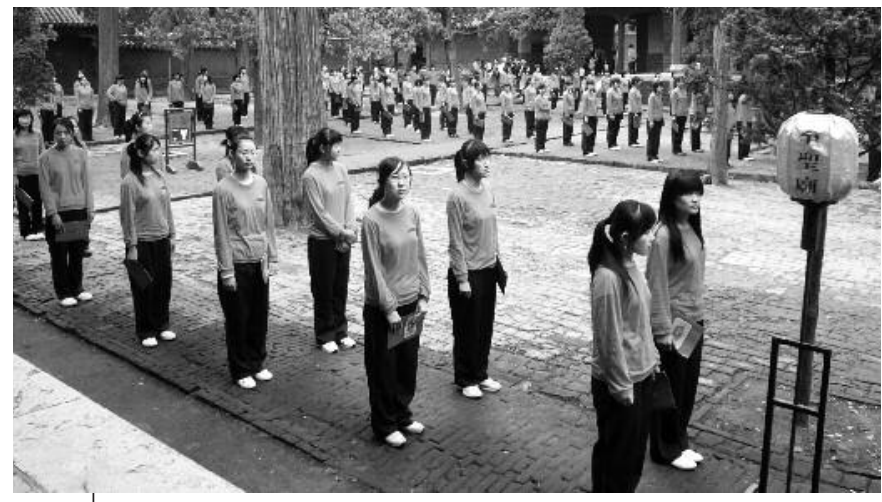

Around 1,000 people attend the early reading of Confucian classics prior to the Kongmiao ceremony. @ Sébastien Billioud

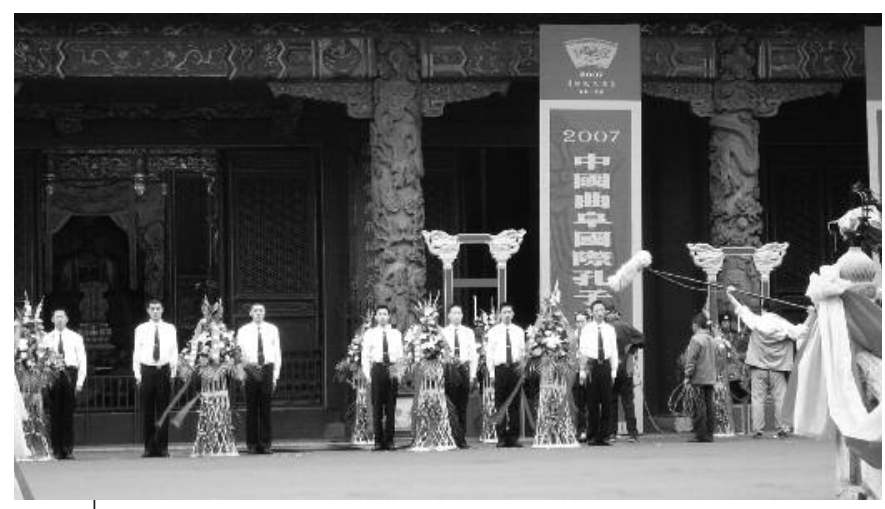

PLA soldiers presenting and displaying offerings. () Sébastien Billioud

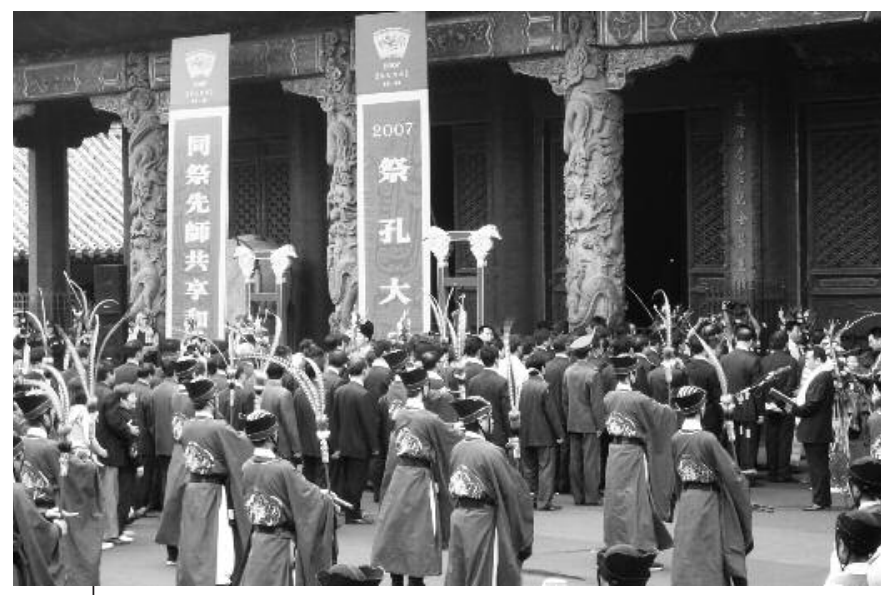

After the main ceremony, another ceremony takes place for representatives of the Kong lineage. ๑) Sébastien Billioud 


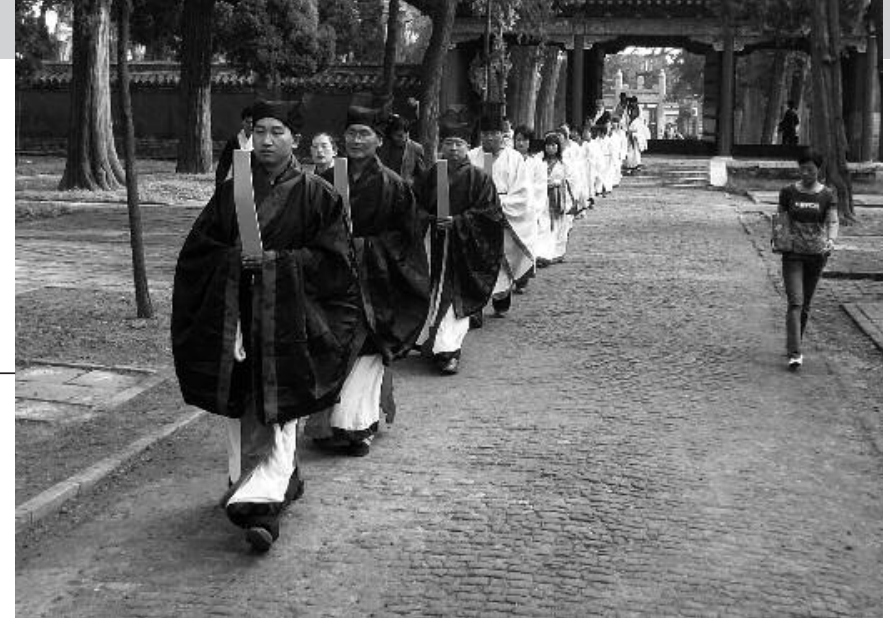

gather on the Way of Spirits (shendao) just outside the old town of Qufu, then line up and head towards the temple. In front of the old wall, they attend a small ceremony known as "setting the holy fire of Chinese culture" (zhonghua wenhua shenghuo).

On the threshold of the temple, the procession merges with another large crowd and descends into confusion. It transpires that the ceremony about to take place follows an early reading of the Analects of Confucius in the temple by 1,000 young people. ${ }^{(36)}$ At the heart of the temple, before the Hall of the Great Accomplisher (Da cheng dian) and its terrace, the chaos ceases in front of a line of PLA soldiers in "civil uniforms" (white shirts, black ties). Alongside the terrace and behind the soldiers, a cohort of young readers of the Analects prepares to celebrate Confucius in his capacity as "Ancient Master."

The ceremony itself is very simple. The delegations of guests (among them a CPPCC Vice-President, Shandong provincial Party secretary, Yu Dan, delegations of overseas Chinese, etc.) invited to honour Confucius are waiting at the foot of the terrace. When instructed, they walk up the stairs one after the other and head towards the altar. Then, for each group of delegates, two PLA soldiers display floral offerings before the altar. The delegates then walk to the floral displays to ritually arrange them (on the right, then on the left); then they step back (three steps) and bow three times (san jugong) before the statue of the Master. ${ }^{(37)}$

Let us emphasise that these extremely simple offerings contrast strikingly with the complex preparation, liturgy, and animal sacrifices offered to Confucius in Imperial China and even up into the contemporary era in Taiwan. ${ }^{(38)}$ During the ceremony, a few excerpts of the Analects are also declaimed, and a prayer (wen) is read. The completion of the offerings by all the delegations is followed by ritual dances performed by a professional dancing troop in Ming dynasty garb. ${ }^{\left({ }^{39}\right)}$ It is worth emphasising here that in the traditional ceremonies to honour Confucius, dances and music were often performed by the scholars-literati themselves, and often by novices. ${ }^{(40)}$ The ceremony ends in complete pandemonium as the terrace is opened to the public.

\section{Grassroots Confucianism and Confucian ceremonies}

A few days after the official festival, a series of much more discreet events takes place in Qufu. These highlight a grassroots

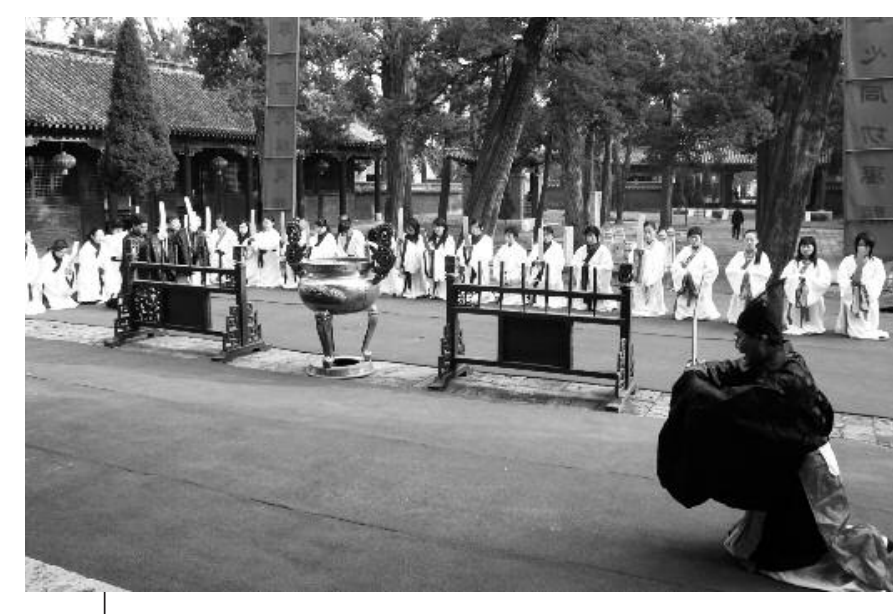

Minjian ceremony in the Mencius temple.

() Sébastien Billioud

or minjian dimension of the so-called "Confucian revival." Ritual ceremonies are organised in the temple of Mencius in the nearby city of Zoucheng and in the Confucius temple in the sanctuary of Nishan. Around the same time, a local association for the promotion of ancient ritualistic culture and music is inaugurated in Qufu, providing an insight into the way minjian Confucianism has to deal with local authorities in order to create a space for its activities.

It is first in the city of Zoucheng, around 30 kilometres south of Qufu, that a group of activists from different locations in China prepares to honour Mencius. Mr. D., the master of ceremonies, is a native of Qufu, where he works as an electrical technician in

35. The titles of the three parts of the program are noteworthy: (1) Tong geng yi luo, si hai gong yang, "Common roots, a single lineage: The four corners of the world joined in admiration [for our culture]"; (2) Tan yun chun yu, he er bu tong, "Spring rain on the almond platform [place in the Confucius temple where the Master used to teach], live in harmony while respecting differences"; (3) Renwen aoyun, sheng shi datong, "Humanist Olympic games, the Great Unity of an accomplished world."

36. For the figure see Qi Lu wanbao, 28/09/2007, p. A3.

37. Field observation and instructions given to the participants before the ceremony: 2007 jikong dadian xu zhi (Things to know before the ceremony).

38. For the Imperial era, see Thomas A. Wilson, "Sacrifice and the Imperial Cult of Confucius," op. cit. For a firsthand testimony regarding the liturgy of ceremonies carried out during the Republican period, see Franz Xaver Biallas, Konfuzius und sein Kult, op. cit., pp. 100-115. On Taiwan, see Joseph S.C. Lam, "Musical Confucianism: The case of Jikong yuewu," in Thomas A. Wilson (ed.), On Sacred Grounds, op. cit., p. 168.

39. On costumes see Joseph S.C. Lam, Ibid., pp. 156-164. The comparison between the illustrations provided by Lam and the costumes of the dancers in 2007 suggest that the model used today is of Ming inspiration. The same troop performed a few days later at ceremonies in the Hong Kong Stadium.

40. Thomas A. Wilson, "Sacrifice and the Imperial Cult of Confucius," op. cit., pp. 266-270. 
a local company. Gradually, he has become the head of both a real and on-line network of people from relatively modest backgrounds interested for a variety of reasons in the revival of Confucian traditional culture. Among them are company employees, local administrative cadres and clerks, craftsmen, primary school teachers, intellectuals who never entered academia, etc. In the present case, the participants include a few cadres, employees, and teachers, as well as a group of young female students from Shaanxi Province Normal University who came as a group along with some of their professors. After some preliminary excitement and confusion during which everyone dresses in Ming garb (which includes wooden tablets and, for the men, the cap of the scholar-literati), the atmosphere becomes more solemn. Lining up in two columns, male participants in the front, the procession walks through the streets of Zoucheng, heading towards the famous temple dedicated to Mencius, the Yashengmiao. ${ }^{(4)}$

The temple is well preserved and relatively protected from the invasion of tourist crowds. Established during the Song dynasty, it offers an atmosphere of quiet and beauty that contributes to the dignity and the solemnity of the ceremony. The participants, around 40 altogether, gather on the terrace

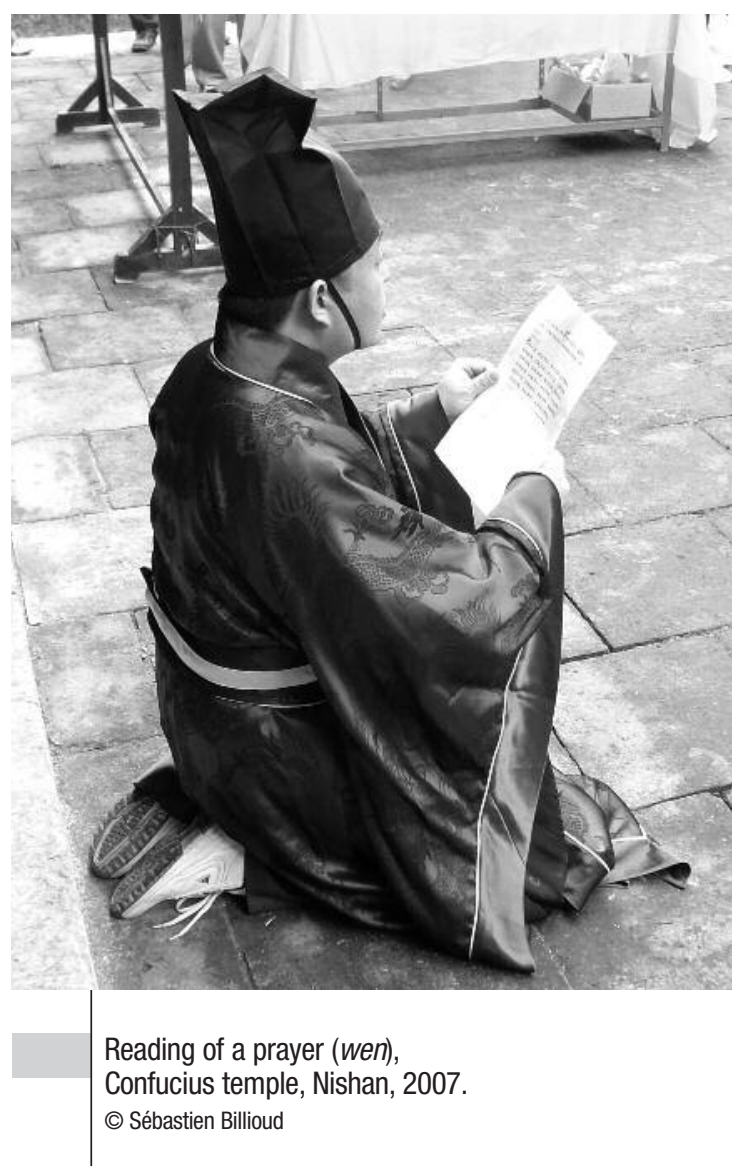

before the main building (the Yashengdian), where they are joined by a few local people. Four or five people perform most of the liturgy, while the role of the other participants is mainly to bow down, kneel down, or kowtow as required. On the terrace, a table is used both for ritual ablutions and the preparation of alcohol offerings in ancient-style tripods. Incense is also burnt. The ritual is quite simple: it consists of a series of ritual gestures (bowing down, kneeling down, kowtowing), offerings of wine and silk inside the temple, kneeling to read out a ritual prayer (a wen, which is not burnt in Zoucheng as it will be a few days later in Nishan), and another series of ritual gestures. In his capacity as master of ceremonies, Mr. D. plays a central role, declaiming with a deep and confident voice all the ritual formulae. The whole ceremony lasts little more than one hour.

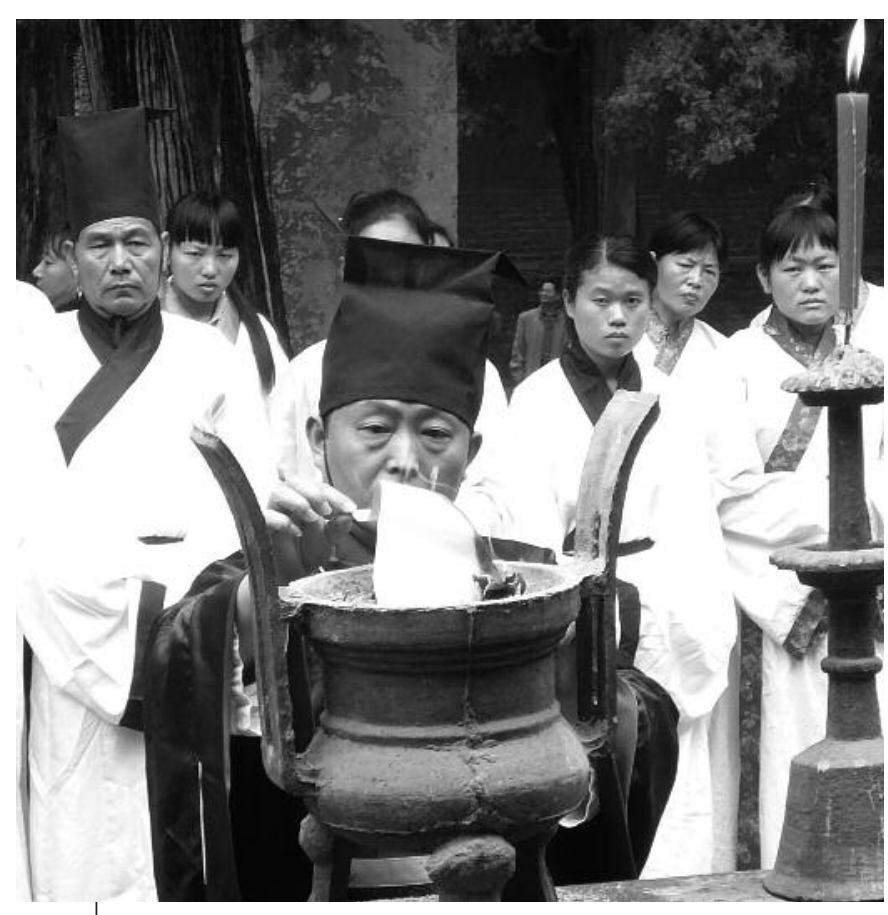

Burning the prayer (wen), Confucius temple, Nishan, 2007. (c) Sébastien Billioud

41. Let us recall here that there are in Zoucheng, as in Qufu for Confucius, three main spaces dedicated to Mencius: The temple, the mansion and the cemetery (Mengmiao, Mengfu and Menglin). 
Ceremony celebrating the founding of the "Holy city society for the promotion of ritual culture and music." ()

Sébastien Billioud

It is a ceremony of another type that takes place the next day in the conference room of a hotel, celebrating the founding of the "Holy City society for the promotion of ritual culture and music" (Shengcheng liyue wenhua cujinhui). Some of the main participants of the Mencius temple ceremonies are here, but in a completely different micro-political context.

Around 60 people take part in the meeting, the objective of which is to officially establish the society and appoint its board of directors. The setting and the sequence of events have been carefully prepared. A large picture of Confucius hangs on the rear wall. Traditional music opens the ceremony, while three categories of people seat themselves at a long table facing the assembly: local representatives of Jining District and the city of Qufu (culture, tourism, and education bureaus), members of the Kong lineage (descendents of Confucius), and Confucian educators and activists acquiring some form of legitimacy through this ceremony.

The ceremony starts with three ritual bows (san jugong) in front of Confucius's picture and the reading of a "decision" praising the "historical" creation of the society. In his capacity as still-provisional vice-president of the Society, Mr. D., the electrical technician who acted as master of ceremonies the day before, gives an overview of the mission of the society: handing down the rites of Confucius and Mencius, promoting "popular education" (minjian jiaoyu) (assistance to local schools, free lessons on the classics, calligraphy, moral education), organising activities related to classical culture for children and events promoting the "Confucian six arts," disseminating information on classical culture and Confucianism, encouraging the movement of rediscovery of classical dress (hanfu yundong), reviving traditional festivals, etc. A few guests from other provinces are then welcomed, and an old carpenter is given the opportunity to evoke with exaltation the homeland of Confucius and the coming Olympic games... The process of appointing the directors of the Society takes place afterwards: a list prepared in advance is submitted to the - obviously unanimous - approval of the participants. Names and titles are in some cases accompanied by the designation "descendent of Confucius" (Kongzi de houyi). The President-elect, Mr. Kong Deban, is a member of the standing committee of the consultative assembly (zhengxie) of Jining. In his speech, he praises the "harmonious socialist society" promoted by $\mathrm{Hu}$ Jintao, the function of "education - transformation" (jiaohua) provided by rites and music, and the role that Chinese culture will increasingly play in the world. This particular ceremony is put in the larger context of a true renaissance of Chinese civilisation (wenming fuxing). Among all the interventions, the most sophisticated is a discourse from a 
From rituals to ideological ceremonials: celebrating a Confucius devoid of Confucianism

One might first wonder how it is possible to articulate a postMaoist ethos inspired by Confucianism and claiming a Confucian identity.

The first portion of the events described above were the result of official initiatives. Indeed, it is authorities at different levels (national, provincial, local) that have organised various gatherings in the Confucius Research Institute, in the modern stadium of Qufu, and in the ancient Confucius temple. Each time, they target specific audiences: academic circles, the masses, the regime's new elite (political and economic). Not too surprisingly, the series of events reflects two characteristics of Chinese society: its ideological background and the increasing merchandising of culture. The ideological agenda intertwines here with the economic needs of local authorities, for which cultural heritage and tourism revenue constitute important trump cards for local development.

One pivotal point to be taken into account is the following: if one considers that ritual lies at the heart of Confucian tradition, the above-mentioned gatherings unveil fundamental performative contradictions. Bluntly put, it is claimed that these official ceremonies and gatherings are organised to celebrate Confucius, but a number of elements suggest that the figure of Confucius celebrated here is more often than not cut off from - if not devoid of Confucianism. If Confucian rituals demand an internal (nei) participation in the ceremony in a spirit of both respect and individual/collective harmonisation of emotions, ${ }^{(42)}$ which fragments of this ancient conception of ritual still survive in planned activities characterised by a prevailing instrumental rationality?

The influence of a post-Maoist habitus - i.e., of a set of post-Maoist cultural dispositions or schemes permeating practice - is manifested differently in the three spots where official gatherings take place. In the Qufu stadium, the figure of Confucius is referred to in various ways, from slogans to commercials, but the event tends to turn into a gigantic show and party for the masses. It is only by borrowing a number of forms usually found in political rallies (speeches, use of symbols, enthusiasm from a minority of activists) that the cultural and ideological dimensions of the event are emphasised and that collective feelings may be channelled in a direction that is not pure entertainment. ${ }^{(43)} \mathrm{At}$ the Confucius Research Institute where the inaugural conference took place, the contrast is blatant between the message of harmony and opening professed in the manifesto and the rigid bureaucratic procedures aimed at the manufacturing of consensus. However, it is of course the official events taking place in the ancient Kongmiao that epitomise the tension between the habitus of the organisers and the ancient ritual spirit that those ceremonies (ji Kong dadian) were meant to celebrate and express.

Let us highlight a number of features of such a tension, a tension that generates, as mentioned earlier, a performative contradiction characteristic of rites devoid of ritual spirit. First, and most blatantly, the ceremony was characterised by the imposing presence of the state apparatus in the form of policemen and PLA soldiers (in "civil uniforms": white shirt, black tie...). In that respect, one could emphasise that ceremonies performed in Qufu to honour Confucius are normally only civil (wen) in nature. But even if we consider that the harmonious combination of the martial $(w u)$ and the civil (wen) is a classical theme of Chinese cosmology (suffice it to mention briefly Hong Kong's numerous wenwu miao, i.e., civil and martial temples), the rigidity of the PLA soldiers and of the young readers chanting quotes of the Lunyu transformed into slogans create, in the present case, an atmosphere hardly compatible with reverence... Moreover, it is a very heterogeneous population that gathered at the temple with a variety of motivations: officials and their many guests, organisers from local institutions, troops of professional dancers, journalists, visitors, a few foreign tourists, etc. This mix of rigidity in the organisation and heterogeneity of the public's expectations combined with an overall ignorance regarding these rites and their ancient meaning. ${ }^{(4)}$

\section{The emergence of a new minjian ritualism}

Taking into account the exterior and instrumental dimension of these official events, it is possible to contrast them with newly observed attitudes in the activities initiated by popular (minjian) Confucian activists.

Both in the Mencius temple and in the Confucius sanctuary of Mount Nishan one encounters a similar circle of activists eager to go some distance with the "Confucius festival" while

42. Let us recall here that historically the notion of $/ i$ (rites) was associated with that of qing (emotions).

43. The "non-entertainment" dimension of the meeting is probably even more difficult to grasp for another section of the public, namely the would-be audience of TV stations broadcasting the event.

44. This remark does not apply to the rites performed after the official ceremony by a delegation of the Kong lineage. 
considering it excessively political and commercial and lacking any direct relationship with the tradition they embrace. A true ritualism, though simple in its forms, makes it possible to gather a larger group of supporters who share their ideals and commitment to a Confucian revival.

The rituals at Zoucheng (Mencius temple) and Nishan do not originate from decisions within the State apparatus but from the desires of people, more often than not from modest backgrounds. It is helpful to provide some examples of their specific itineraries in order to understand why and how a vague interest in the revival of the tradition translates into concrete practices borrowed from such a tradition. The case of one of the main organisers of the minjian activities, Mr. D., enables us to better understand the gradual transition process between an imaginary dimension of Confucianism and its living reality. Mr. D., who was born in 1969 in Qufu, insists that his interest in Confucianism is not the product of an encounter with someone or with an outside doctrine:

Contrary to many intellectuals who have only recently realised the importance of Confucianism, I encountered it during my childhood. At that time, the temple of Confucius was silent and deserted, but it was for me the best of playgrounds. I also frequently enjoyed wandering across Konglin, the "forest" that constitutes the large cemetery of Confucius's descendants. I was impregnated with this atmosphere and have always had a feeling of closeness with the culture of Qufu. When I entered secondary school I was interested in history and preferred to read books related to the classics despite the opposition of my teachers..." ${ }^{(45)}$

Mr. D. experienced very early, at an age when he was not really able to understand the meaning of such an emotional state, a feeling of belonging to a civilisation with an infinitely valuable past but that had somehow become ossified due to all the attacks, destruction, and waves of censorship it had suffered. It was entirely by his own initiative that he attempted in the 1980s to translate his vague intuitions into more explicit values. This individual quest took the form of solitary study of texts and daily writing, starting from the 1990s, of a personal diary used as a tool of moral self-cultivation. He spent some time in Shenyang to be trained as an electrical technician, and decided afterwards to settle down in his native town. Quick to understand the potential of the Internet for the promotion of traditional culture, he developed a little network of sympathisers of Confucianism that has now extended throughout the country.
In 2004, he built a virtual on-line "academy," the Zhusi shuyuan, in reference to Confucius's study hall on the Sihe River. This website served as a tool for the promotion of classical texts, the establishment of a small group sharing an interest in Confucianism, and the organisation of ritual ceremonies within the "space of the people" (minjian). ${ }^{(46)}$

We started to organise ritual ceremonies in 2004. These cults (jisi huodong) could take place in the Kongmiao. In accordance with tradition and contrary to the official festival, we honour Confucius twice a year, in Spring and in Autumn. Once we had 270 believers (xinyangzhe). People establish contact with each other on an individual basis. When they are fond of these rites, they contact each other and organise themselves. They are people from a variety of different backgrounds, not scholars... ${ }^{(47)}$

On the basis of rituals observed in 2007 in the temple of Mencius and in Nishan, one can only highlight how different the spirit of these ceremonies is from that of the official festival in the Confucius temple. The small group collectively performing the rites is here made up of individuals from different backgrounds who probably have very different imaginary representations Confucianism. But one has to acknowledge the existence of a true ritual community. Firstly, the overall atmosphere of these ceremonies is both solemn and devoid of rigidity. Since the participants' historical and practical knowledge of these rituals varies, it is $\mathrm{Mr}$. D. who takes the role of ritual master. He is the central figure of these ceremonies, due both to the respect attached to his long-standing dedication to Confucianism and to his longer experience with the rites. However, he is not a ritual specialist in the sense that this category applies to someone who has been initiated within a clearly codified ritual tradition. It is indeed a striking feature of the current Confucian revival to see many activists rediscover or reinvent (e.g., through ancient texts) the rituals associated with Confucian ceremonies. In the present case, the performance of each phase of the ritual generates brief discussions between the main participants: they raise concrete questions about appropriate gestures and the positioning of the masters of ceremonies outside and within the temple, the way of presenting offerings,

45. Interview, Qufu, March 2007.

46. On Mr. D.'s activism, see the report in Kang Xiaoguang's Dongdai Zhongguo dalu wenhua minzuzhuyi yundong yanjiu, Hong Kong, Global Publishing, 2008, pp. 104-110.

47. Interview, Qufu, March 2007. 
the proper transition between different steps of the ceremony, etc... In fact, such a ritual practice actually paves the way for self-transformation, both at the level of the individual and at the level of the group. Since none of the participants is an expert, the whole group is engaged in a mutual self-learning process, the physical impact of which is genuinely impressive. The ceremony that started in a friendly and joyful atmosphere gradually acquires a real solemnity. The original awkwardness of gestures and postures progressively turns into a collective attitude of reverence (jing). In other words, bodies that only a short time ago reflected the daily habits of technicians, primary school teachers, craftsmen, or minor cadres undergo a radical transformation through the very performance in which they are engaged. Movements become slower and increasingly fluid, a transformation especially obvious during the offerings to Mencius or when a wen (prayer) is read and punctuated by interjections uttered by Mr. D. with a calm, loud voice. Linking the individualities, a single ritual body takes shape, through which ritual efficiency is attained...

The solemn beauty of the places where these rites took place, as well as the feeling of facing the ancient sages, contributed to an atmosphere of reverence far from the noise and the exteriority of official ceremonies. Other attempts by the same group to nurture a ritual spirit translated into the organisation of the "first cantonal banquet rite and second archery rite of the holy city" (Shengcheng shoujie xiang yinjiu li, dierjie shili yishi ). But here it seemed that these "popular Confucians" reached the limits of their ritualistic dreams. While places such as the Yashengmiao or Nishan, endowed with the prestige of a long religious history, seemed to offer proper conditions for the realisation of convincing rites, one can question to what extent their other attempts to ritualise human relations (banquets, archery) have produced more than parodies of rituals or a vain nostalgia towards fragments of Confucian heritage.

\section{Interactions between "popular" and "official" Confucianism}

In spite of the contrasts highlighted above, one cannot simply oppose popular (minjian) to official (guanfang) Confucianism. These two denominations rather constitute two extremities of a continuum within which many different attitudes are possible.

Let us first emphasise that it is possible to find in China at the start of the new century numerous spaces that could be termed "equivocal," by which is meant that actors pursuing distinct strategies (if not contradictory ones) are nevertheless able to interact by relying on a similar discourse and comparable behavioural codes. It is only by exploring specific contexts that one may determine whether the people involved tacitly accept a polysemy of symbols they refer to or whether they deliberately use a dual language. At that point, it is necessary to point out that this "strategic equivocality" can be understood within a more general framework of transaction and negotiation on cults, myths, and symbols between different players (authorities, local or central; various social groups) - a framework that can be traced back to the imperial era and that is being perpetuated under a new guise in the post-Maoist era. In his work on Guandi, the God of War, Prasenjit Duara introduces the concept of superscription to discuss how rival versions of a myth may "jostle, negotiate and compete for position" without, however, erasing each other. ${ }^{(48)}$ Michael Szonyi, in his study of the cult of the five emperors in late imperial China, shows that official efforts to standardise the gods and impose a model of superscription may fail when facing the resilience of local cultures capable of producing the illusion of compliance with statesanctioned discourses and policies. ${ }^{(49)}$ As will be discussed below, the equivocality observed in our contemporary Confucian context echoes these various analyses of intertwined layers of meaning and discourse.

One can already posit that the equivocality originates neither with the authorities nor at the grassroots level: it is widely shared across most of the behaviours, and probably makes it possible to characterise the post-Maoist ethos of popular Confucianism today. But this was, after all, to be expected. It would have been indeed surprising not to find in activists' circles traces of several decades of communist rhetoric and moulding of minds and bodies. Let us here illustrate this point. A 37-year-old cadre came from Shaanxi Province in order to join the popular activities organised by Mr. D. A Party member and at the same time one of the itinerant Confucian militants supporting revivalist efforts wherever they take place, Mr. G. retains through his clothes, attitude, and language the image of the cadre he has always been. However, his embrace of Confucian ideals has the character of a true conversion. "I have decided," he says, "to fully dedicate myself to a Confucian research society in my province and to

48. Prasenjit Duara, "Superscribing Symbols: The Myth of Guandi, Chinese God of War," The Journal of Asian Studies, Vol. 47, no.4, Nov. 1988, pp. 778-795.

49. Michael Szonyi, "The Illusion of Standardizing the Gods: The Cult of the Five Emperors in Late Imperial China," The Journal of Asian Studies, Vol. 56, no.1, Feb.1997, pp. 113135. 
launch a website to go with it." He adds, laughing, "In a way, I have remained a professional revolutionary!"

The fact is that Mr. G. devotes all his proselytising energy to his cause, as well as apparently very good organisational skills. Following the example of his daughter, who joined classics reading classes, he has himself learned the four books by rote, using first a local method and then the pedagogy of Taiwanese educator Wang Caigui. He is now able to recite Confucius' Analects or the Mencius with the same quick and uniform voice. During the Mencius ritual, he put a yellow scarf around his neck but did not dress in Ming garb. Somehow, he took the role of the person in charge of public relations, dealing with the few visitors who joined the ceremony on site and inviting some of them to pay tribute to Confucius through a rudimentary ceremony. $\mathrm{He}$ also attended the inaugural meeting of the local society for the promotion of rites and music described above. On that occasion, he delivered a prepared speech during which he read with fervour a number of phrases in classical Chinese. His rhetoric and body language looked very much like those of a propaganda specialist indulging his own convictions.

The organisation of the ceremony for the foundation of the society for the promotion of rites and the presence of representatives of local authorities (education, tourism, culture) shows that a network of activists such as that of Mr. D. (appointed vice-president of the society) needs some recognition through an institutionalisation process. The keynote speech of the ceremony thoroughly echoed official rhetoric and ideology:

\section{Distinguished leaders and comrades:}

The creation of the Society for the Promotion of Rites and Music of the holy city of Qufu has a special historical significance. According to the Classics of Rites, there is nothing that transcends music's ability to improve morals and transform habits, and nothing that transcends the ability of rites to ensure the equanimity of the King and the good government of the people. This ritual culture was a unique creation of the ancestors of the Chinese nation to express their entry into civilisation. Its main social function lies in its dimension of education-transformation (jiaohua). Rooted in the life of the nation, serving the development of society, it is a system that unites transformation of the self, regulation of the country and harmonisation of the world. The Society that we are founding today will rely on rites and music to encourage people to respond to the commands of the Way, be it through their inner life or in their outward behaviour, and thereby shape an ideal life based on harmony. We must strive to promote the great traditional culture of the land of Confucius and the great renaissance of Chinese culture!

At this meeting attended both by Confucian activists and local authorities, some amount of "concession" to official rhetoric and ideology (e.g., "rooted in the life of the nation, serving the development of society"; ambiguous reference to "harmony," etc.) illustrates the afore-mentioned equivocality that permeates the spaces where Confucianism develops today. We are here approaching Duara's idea of superscription, described, in the context of the God of War, as "enabl(ing) the imperial state to create an authoritative image of Guandi with which rural elites could identify and other social groups could acknowledge without renouncing the dimensions of Guandi that were more immediately relevant to them." ${ }^{(50)}$ In our case, minjian activists have no problem integrating the official vulgate for the sake of negotiating a space for their activities, but this acknowledgment in no case means that they are not at the same time relatively autonomous. An outsider who would simply take into account an officially sanctioned society largely monitored by power (i.e., here by local authorities) would easily label these Confucian revivalists "instrumentalised activists." But whereas some degree of instrumentalisation certainly exists, ${ }^{(51)}$ it is also largely, in Szonyi's terms, illusory. Indeed, one often encounters in circles of activists a very strong awareness that their commitment to a Confucian ideal anchored in history goes far beyond the current political circumstances and necessary concessions to the prevailing ideology. Such an awareness is often reinforced by the conviction that the decisive strength that will make a future "Confucian revival" possible will not primarily come from the elites or from the powers but from the people themselves. The "prayer" (wen) addressed to Mencius during the above-mentioned temple ceremony provides an illustration of such a point through the fact that it was read in the name of a community of so-called minjian xuezhe:

50. Prasenjit Duara, "Superscribing Symbols: The Myth of Guandi, Chinese God of War," op. cit., p. 791.

51. Even this statement could be challenged. The fact is that in the area of Qufu, the descendants of the Kong lineage remain extremely powerful. The president-elect of the society for the promotion of rites and culture, Mr. Kong Deban, is a member of the standing committee of the consultative assembly (zhengxie) of Jining. He manages to represent both the authorities and the lineage, i.e., the Confucians. One has good grounds to wonder who is instrumentalising whom.. 
coming from the "space of the people," these self-made scholars and itinerant activists are organising themselves according to their own rules, and are not striving for any academic or official recognition beyond what might facilitate their activities.

The shared awareness of a mission to fulfil (the renaissance of Confucianism) has developed within a number of networks that often start locally and then expand to other circles through the extraordinary dynamism of Internet communication. It is possible to borrow from Hoyt Tillman the expression "fellowship of the Way" (22) (originally applied to neo-Confucian Song reform) in describing the situation: Internet makes it possible to attract people from extremely different horizons and backgrounds who are eager to join each other to share values and practices, be they social, educational, or religious. An example of the efficiency of these networks is given by the presence, during the foundation ceremony of the Qufu ritualistic society, of an activist encountered by the authors of this study in Zhuhai and involved in a local autonomous "academy." ${ }^{(3)}$ But there are limits to what can be achieved though the Internet, and such a "fellowship of the Way" acquires greater reality through the concrete participation of activists in these Confucian ceremonies. Indeed, by enabling people from completely different social backgrounds and geographical origin to meet, these ceremonies and their related activities ${ }^{(54)}$ are instrumental in creating true communities of "believers" and activists whose commitment to Confucianism is strengthened through this performative process.

The relative autonomy of these minjian activists does not mean that they are not ready to engage with the "elites." It is possible to have good relations with scholarly circles, but the latter are considered partners and not masters. Besides, even while sharing the conviction that the most important work is proselytising "within the space of the people," Confucian activists also develop relationships with cadres sympathetic to their cause. But it is essential to note that Confucian activists are obliged to look for local institutionalisation in order to develop their activities. It is at the grassroots level that they take the initiative and ask for the support of the authorities. In this respect, the situation resembles that of the reactivation of myriad popular religion temples that are technically illegal, since they are not associated with one of the five religions officially recognised on the mainland. Analysing a number of ethnographic surveys carried out in temples located in various parts of the country, David Palmer emphasises that temples often manage to diffuse anticipated tensions with local authorities and negotiate some space for their activities. ${ }^{(5)}$ This does not sound very different from the case of our society for the promotion of rites and music:

\begin{abstract}
The various departments of local government, when considering Mr. D. and his project of society, have switched from their original attitude of non-understanding and non-intervention towards a more open attitude that has gradually turned into relative support. (...) local cadres came little by little to acknowledge the value of ritual activities (jisi) and finally accepted their principle. Thus, the department of tourism granted them some facilities... ${ }^{(56)}$
\end{abstract}

The reference to the department of tourism certainly hints at one of the motivations of local authorities (development), which is also a central consideration in negotiations with popular religion temples. But there may be specificities linked to the very nature of Confucianism, which local cadres generally do not associate - even in its ritualistic form - with religion or minjian xinyang and their halo of "superstition." It is therefore easier for Confucian activists to gain the support of a number of local cadres sympathetic to the prestige of "high culture" and the role it could play again in China today. In the present case, it is the activists who are actually providing local cadres (some of them supportive, but ignorant of the historical context of these rituals) with the discourse and "traditional references" that enable them to gradually legalise and institutionalise these minjian activities. ${ }^{(57)}$

There is little room in the frame of this limited study for more general considerations on the nature of the relations between Confucianism and state authority in China. Indeed, Confucian activism is often (although not always) co-exten-

52. Hoyt Tillman, Confucian Discourse and Chu His's Ascendency, University of Hawaii Press, 1992, pp. 2-4.

53. This is just one example linked to Qufu. However, we encountered a number of similar cases in other locations and contexts while carrying out fieldwork.

54. All in all, the minjian activities that we could attend in 2007 in Qufu lasted several days. Apart from the ceremonies themselves, there were a number of other activities and common meals that enabled the people to genuinely become acquainted with each other.

55. David Palmer, "Religiosity and Social Movements in China, Divisions and Multiplications," in Gilles Guiheux and Khun Eng Kuah-Pearce (eds.), Social Movements in China and Hong Kong, The Expansion of Protest Space, Amsterdam, Amsterdam University Press, 2009, pp. 265-273. Palmer also notes that "a recurring picture emerges in several of these studies, of a constant 'tug-of-war' over the uses and appropriations of public spaces" (p. 265).

56. Kang Xiaoguang, op. cit., p. 109.

57. In Qufu, this little group is very much aware of its role of initiator and re-creator of a tradition that was forgotten for a long period of time. They are proud that their commitment led to a Confucian ritual being organised at Mount Nishan in 2007, "for the first time since 1949." 
sive, integrated, and in constant negotiation with the state apparatus at the local level. In that respect, the situation in Qufu is only one of many examples that the authors of this article encountered in the course of fieldwork. In Dongguan (Guangdong), it is within the municipality that Confucian activists and cadres have joined to convince the hierarchy to support local sishu (classical schools) promoting rote learning of Confucian classics. ${ }^{(58)}$ In Beijing, it is also with the authorisation of its top management that a public company in the sensitive media sector - an internet channel of CCTV - now demands that all applicants for employment be able to memorise the Rules of the Disciple (Dizigui, a Confucian classic) and wear a tie emblazoned with Confucius's portrait at work... ${ }^{(59)}$ In Bangbu (Anhui), consultants for the municipality who are Confucian converts have convinced the local authorities to host learning sessions on Confucianism and traditional culture for the cadres of the local government. ${ }^{(60)}$ In Shaanxi, it is within local governmental structures that a society for the promotion of Confucianism and traditional culture has been created by "Confucian cadres." ${ }^{(61)}$ Many more examples could be cited to demonstrate that the development of this "Confucian revival" shares a number of features with the qigong episode studied by David Palmer and characterised in the following way: "a movement that developed through the interpenetration of networks; groups, institutions, practices and conceptual systems, in which it is impossible to fully separate the state and popular groups as distinct entities"... ${ }^{(62)}$ But in our view, what the Qufu case more specifically highlights is the often neglected role of grassroots initiative and creativity in the mutual imbrication of "minjian" and official Confucianism.

\section{Conclusion}

The elements discussed above offer some limited perspectives on the relationship between politics and Confucianism in contemporary China. This is especially the case due to their local dimension. In spite of the authorities' wish to ascribe to the Confucius festival a national and international dimension, it is in reference to the special situation of Shandong Province and the cities of Qufu and Jining that the "popular" (minjian) events described above need to be understood, even though we observe the phenomenon of interpenetration between Confucian activism and the state apparatus in many different locations.

One prevailing analysis regarding China's political evolution acknowledges the development of a kind of cultural nationalism that identifies the resources of a new political legiti- macy within the Chinese cultural tradition (taken broadly, not necessarily in direct reference to Confucianism). A number of signs given by the authorities, as well as research conducted on the topic, provide grounds for such an interpretation. Nevertheless, the experiences of popular movements describing themselves as Confucian invite us not to reject but to qualify such an understanding of the situation.

Firstly, it would be worthwhile to explore more thoroughly and at different levels of Chinese society what could be called, echoing the title of Wm. Theodore de Bary's wellknown book, ${ }^{(63)}$ "the trouble with Confucius": an essential difficulty in dealing with the very figure of the Sage. Indeed, other elements borrowed from Chinese tradition might be much more useful than Confucianism in shaping a modern nationalist project. Observing the variety of events taking place within and besides Qufu's festival suggests that the figure of Confucius is not necessarily easy to manipulate. But is that so surprising? After all, it is not possible to forget that Chinese nationalism, under both its Republican and Communist forms and from May Fourth to the Cultural Revolution, considered that realising its ideals required "deconfucianising" China as much as possible. The "Zhonghua minzu" ideology was originally elaborated in an anti-Confucian spirit.

It would be interesting to compare, including from a local perspective, the current appropriation of Confucius with that at the beginning of the twentieth century of another tutelary figure of Chinese tradition, namely the Yellow Emperor. Terence Billeter has shown the relative historical continuity of the cults honouring Huangdi in the sanctuary of Huangling (Shaanxi), from the Kuomintang to post-Maoist eras. ${ }^{(64)}$ These cults were re-established between 1953 and 1963, then abandoned when Mao turned more radical, only to resume in the 1980s and 1990s. It is clear that the very figure of the Yellow Emperor, revered not only as a cultural hero but also as the mythical Ancestor of the Chinese, encourages a more exclusive conception of the nation that is based on descent and race as well as on cultural legacy. The

58. Field work observation, Dongguan, Guangdong, 2006.

59. Field work observation, Beijing, March 2009.

60. Field work observation, Bangbu, Anhui, 2005.

61. Information gathered while doing fieldwork in Zoucheng, Shandong, 2007. This case will be the subject of upcoming fieldwork.

62. David Palmer, "Religiosity and Social Movements in China, Divisions and Multiplications," op. cit., p. 277.

63. Beyond Confucius himself, Theodore de Bary, in The Trouble with Confucianism, Harvard University Press), 1991, discusses the modern fate of "confucianism" in general.

64. Térence Billeter, L'empereur jaune, Paris, Les Indes Savantes, 2007. 
(1)

figure of Confucius that is often referred to in the 2000s (although this is not necessarily universal) might propose a more acceptable alternative in a global world, especially if one considers that the point is no longer to preserve the country's existence, but rather to project a so-called soft power.

However, observation of a variety of local phenomena, be they official or popular (minjian), shows that this figure cannot simply be used as a tool to serve the narrow ideology of a nation-state. Confucianism generates a number of solidarities, both within and beyond the framework of a nation. Beyond China, it refers to a cosmic order, or in other words, to a worldview endowed with a universal dimension. The universalism of Confucian values such as benevolence (ren) or li (ritual) was indeed incorporated in a sophisticated way by the scholars attending the Inaugural World Confucian Conference. Even though it was opposed to a competing univer- salism of Western origin, Confucianism could not simply be put to the fore as the epitome of a national distinctiveness. Indeed, to put things bluntly, it is not simply the "business" of "the descendants of Yan and Huang."

Above all, at the local level, "national" patriotism is only one component of the commitment of Confucian activists, and not necessarily the prevailing one. Their enthusiasm crystallises in the formation of new communities and finds its inspiration elsewhere than in modern ideologies. Their educative or religious proselytising activities generate a need for alliances or negotiations with and within the State apparatus. These, however, far from revealing the firm grasp of the authorities on "the space of the people," rather reflect a number of equivocal strategies and discourses on the side of the activists to diffuse potential tensions and promote their cause. $\bullet$

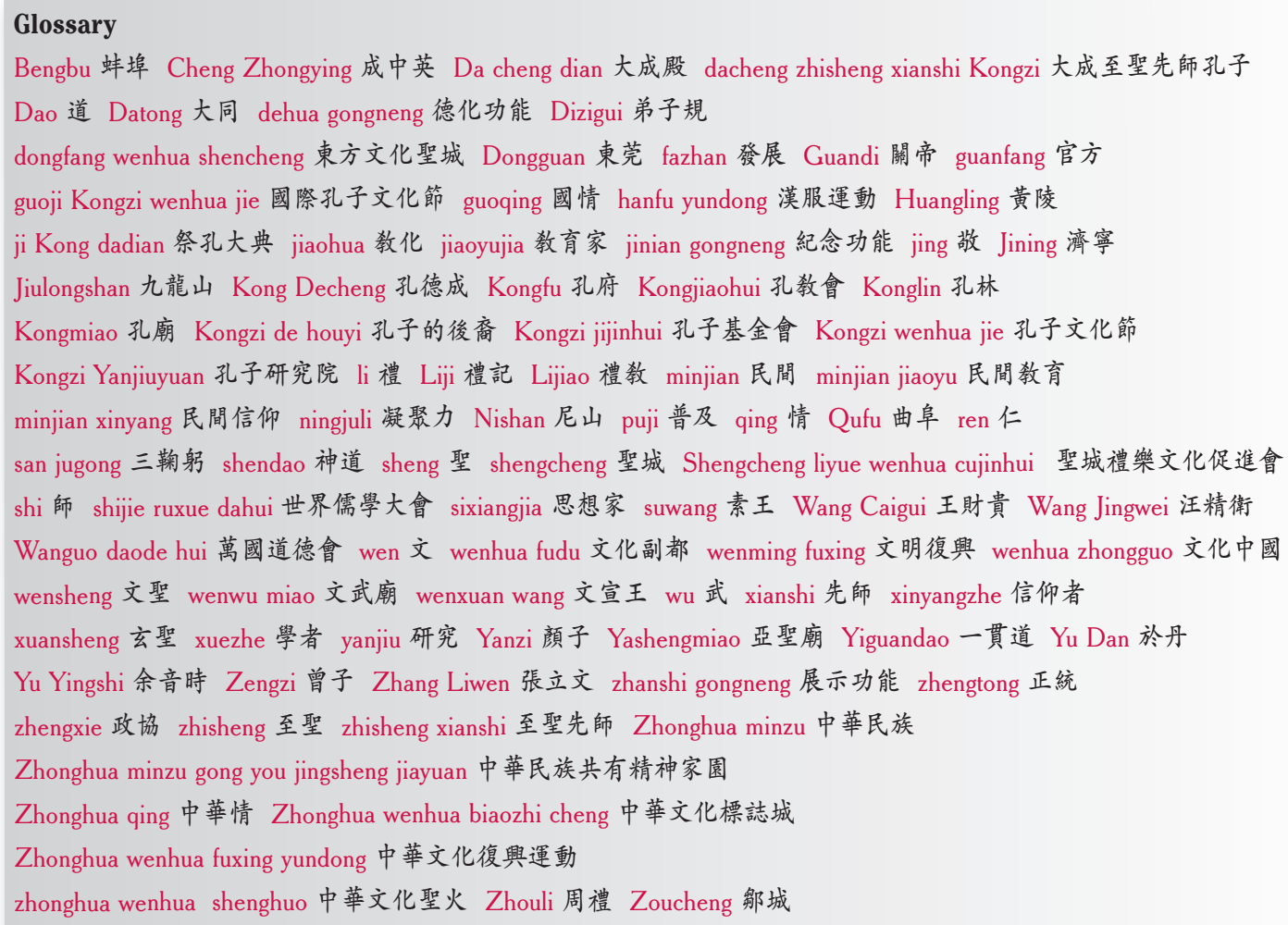

